\section{Cellular Physiology} and Biochemistry Published online: May 09,2016

Accepted: March 16, 2016

This article is licensed under the Creative Commons Attribution-NonCommercial-NoDerivatives 4.0 International License (CC BY-NC-ND) (http://www.karger.com/Services/OpenAccessLicense). Usage and distribution for commercial purposes as well as any distribution of modified material requires written permission.

Original Paper

\title{
NU7441 Enhances the Radiosensitivity of Liver Cancer Cells
}

\author{
Chuanjie Yang ${ }^{a}$ Quanxu Wanga Xiaodan Liu ${ }^{b}$ Xiulian Cheng ${ }^{c}$ Xiaoyu Jiang ${ }^{a}$ \\ Yuan Zhang $^{\mathrm{a}}$ Zhijie Feng ${ }^{\mathrm{a}}$ Pingkun Zhou ${ }^{\mathrm{b}}$ \\ aDepartment of gastroenterology, the Second Hospital of Hebei medical University; Hebei key \\ laboratory of gastroenterology, Hebei institute of gastroenterology, Shijiazhuang, 'D Department of \\ Radiation Toxicology and Oncology, Beijing Institute of Radiation Medicine, Beijing, 'Department of \\ gastroenterology, the first Hospital of Zhangjiakou city, Zhangjiakou, China
}

\section{Key Words}

NU7441 • Hepatocellular carcinoma - Radiosensitization • Non-homologous end joining • DNA-PK

\begin{abstract}
Objective: Radiation therapy, one of the major treatments for liver cancer, causes DNA damage and cell death. Since the liver cancer cells have a strong capacity to repair irradiative injury, new medicines to enhance this treatment are urgently required. In this study, we investigated the effect of NU7441, a synthetic small-molecule compound, as a specific inhibitor of DNAdependent protein kinase (DNA-PK) in radiosensitization of hepatocellular carcinoma HepG2 cells. Methods: Cell Counting Kit-8 (CCK-8) was first used to evaluate the proliferation of HepG2 cells under NU7441 treatment. SDS-PAGE and Western blot were then performed to study the protein expression leading to the DNA damage repair. Further, neutral single cell gel electrophoresis and immunofluorescence assay were carried out to assess DNA repair. Finally, flow cytometry was implemented to examine the changes in cell cycle. Results: NU7441 reduced the CCK-8 counts in the HepG2 culture, further enhanced ${ }^{60} \mathrm{Coy}$ radiation injury to HepG2 cells, which was manifested by decreasing the DNA-PKcs (S2056) protein expression, increasing $\mathrm{YH} 2 \mathrm{AX}$ foci number, prolonging the tail moment of the comet cells, and inducing cell cycle arrest at G2/M phase. Conclusion: NU7441 inhibited the growth of liver cancer cells, enhanced the radiosensitization of these cancer cells by interfering with the DNA repair and cell cycle checkpoint. These data implicate NU7441 as a potential radiotherapy sensitizer for the treatment of liver cancer.

\section{Introduction}

Primary liver cancer ranks the third among the death-leading tumors worldwide [1, 2]. In the developing countries, liver cancer is predominantly caused by infection with the hepatitis B virus (HBV), whereas in the developed countries, the incidence of this disease 


\section{Cellular Physiology Cell Physiol Biochem 2016;38:1897-1905 \begin{tabular}{l|l} 
and Biochemistry Published online: May 09, 2016 & $\begin{array}{l}\text { D) } 2016 \text { The Author(s). Published by S. Karger AG, Basel } \\
\text { www.karger.com/cpb }\end{array}$ \\
\hline
\end{tabular} \\ Yang et al.: NU7441 Enhances Radiosensitivity}

is associated with hepatitis C virus infection and non-alcoholic fatty liver [3]. Current treatments for liver cancer include surgical operation, chemical therapy, radiation therapy, transcatheter arterial chemoembolization, and molecular-targeted therapy. Since no distinctive symptoms are manifested in the early stages of liver cancer, most patients are diagnosed at late stages of cancer development, and few treatment options can be used so far [4]. With the development of modern technologies, such as 3D radiation therapy, intensity modulated radiation therapy, and image-guided radiation therapy, radiation therapy has become one of the major alternatives for liver cancer treatment $[5,6]$. Ionizing radiation (IR) can induce double-strand breaks in the genomic DNA of the targeted cells [7]. Eukaryotic cells can repair their damaged DNA through two mechanisms: non-homologous end-joining (NHEJ) and homologous recombination. NHEJ is the repair mechanism for the radiationinduced double-strand breaks $[8,9]$. DNA-dependent protein kinase (DNA-PK) is a protein of critical importance for NHEJ. DNA-PK consists of three subunits: one catalytic (DNA-PKcs) and two regulatory (Ku70 and Ku80). DNA-PKcs is a core protein responsible for the complex function [10]. DNA-PKcs functions are dependent on its self-phosphorylation at serine 2056 site, pDNA-PKcs (S2056). Liver cancer cells have a strong capacity to repair DNA damage, which is the main reason for cancer recurrence after radiation therapy. Therefore, targeting DNA damage becomes an effective approach to increase the efficiency of radiation therapy.

Presently, investigations have been performed on the effects of many radio-sensitizing reagents, including Curricumin [11], Celecoxib [12], and Saikosaporin[13], and specific inhibitors, such as YM155 [14] (inhibitor of survinin) and DNA-PK inhibitors. NU7441, a derivative from LY294002, is a synthetic and specific DNA-PK inhibitor. In in vitro experiments, NU7441 exerted radiosensitizing activity in breast cancer, leukemia, and prostate cancer [15-17]. However, no studies have been performed to examine the effect of NU7441 on liver cancer cells. To elucidate whether NU7441 can enhance the radiation-induced damage in liver cancer cells (HepG2), we used ${ }^{60} \mathrm{Co} \gamma$ radiation treatment. We found that this inhibitor can work as a radiosensitizer, inducing DNA damage, cell-cycle arrest, and apoptosis. We also discovered that NU7441 targets DNA-PKcs (S2056), which is a potential mechanism for blockage of DNA damage, providing a foundation for the clinical application of this medicine.

\section{Materials and Methods}

Cell culture and treatment with NU7441 or ${ }^{60} \mathrm{Co \gamma}$

Human liver cells LO2 and human liver cancer cells HepG2 were derived from the Beijing Military Medical Institutes, China. LO2 cells were cultured in RPMI media (Hyclone) and HepG2 cells were cultured in DMEM (Hyclone). Fetal bovine serum (10\%, Hyclone) was added in both media. ${ }^{60} \mathrm{Co} \gamma$ was ordered from the Institute of Radiation Medical Research, Chinese Academia of Military Medical Sciences. Radiation exposure was performed at room temperature for 3 minutes and 25 seconds, with a dose of 4 Gy and a dose rate of $111.84 \mathrm{cGy} / \mathrm{min}$.

Measurements of cell proliferation by Cell Counting Kit-8 (CCK-8)

HepG2 cells (4000 per well) were cultured in a 96-well plate for $24 \mathrm{~h}$. Once the cells completed the attachment, $0.1 \mu \mathrm{M}, 1 \mu \mathrm{M}, 5 \mu \mathrm{M}$, and $10 \mu \mathrm{M}$ of NU7441 were added to the culture media. After $12 \mathrm{~h}$ of NU7441 treatment, 10\% CCK-8 solution was added into the culture media, and the incubation continued for two h. OD450 values were determined by a spectrometer, and the results were analyzed to measure the cell growth.

Detecting of protein expression by Western blot

Total proteins $(100 \mu \mathrm{g})$ isolated from these cells were loaded on gel and separated by sodium dodecyl sulfate polyacrylamide gel electrophoresis (SDS-PAGE), and further transferred to a nitrocellulose (NC) film. The protein samples on the NC film were blocked with 5\% milk, incubated with the first antibody (1:1000 diluted in the blocking solution) at $4{ }^{\circ} \mathrm{C}$ overnight. Subsequent incubation with the secondary antibody (1:4000 diluted in the blocking solution) was performed for one hour at room temperature. The NC film 


\section{Cellular Physiology Cell Physiol Biochem 2016;38:1897-1905 \begin{tabular}{l|l} 
DOI: 10.1159/000445551 & $\begin{array}{l}\text { O 2016 The Author(s). Published by S. Karger AG, Basel } \\
\text { www.karger.com/cpb }\end{array}$
\end{tabular} \\ Yang et al.: NU7441 Enhances Radiosensitivity}

was washed three times with the Tris-buffered saline solution plus $0.1 \%$ Tween 20 (TBST). The signals were developed with enhanced chemiluminescence (ECA) system. The antibodies used in this study were purchased from the following companies: anti- $\beta$-actin (Invitrogen), anti-DNA-PKcs (Santa Cruz), anti-DNAPKcs (S2056) (Abcam), anti-Ku70 (Abcam), anti-Ku80 (Abcam).

Detection of $\gamma H 2 A X$ foci by immunofluorescence staining

HepG2 cells treated with NU7441 or ${ }^{60} \mathrm{Co} \gamma$ IR were collected and loaded on the cover slips which were pre-inserted into a 6-well plate. The cover slips with the attached cells were fixed with 4\% paraformaldehyde, permeabilized with $0.25 \%$ Triton-100 for $20 \mathrm{~min}$, blocked with 1\% BSA for $30 \mathrm{~min}$, and incubated with Anti-gamma H2AX (S139) (Millipore, 1:500 diluted in 1\% BSA) overnight at $4{ }^{\circ} \mathrm{C}$. After washing with PBS three times, the slide samples were incubated with the fluorescence-conjugated secondary antibody for one hour at room temperature and counterstained with $1 \mu \mathrm{g} / \mathrm{mL}$ DAPI. The fluorescence images illustrating the $\gamma \mathrm{H} 2 \mathrm{AX}$ foci were captured and visualized under a confocal microscope.

DNA damage repair analysis by single-cell gel electrophoresis (comet assay)

Normal melting agarose gel (1\%) was first loaded onto the slides. After the gel solidified, approximately 1000 cells pre-mixed with $0.65 \%$ low-melting agarose gel solution were loaded on top of the first agarose gel. The slides with the cell samples were lysed in the pre-chilled neutral lysis buffer for two hours at $4{ }^{\circ} \mathrm{C}$, washed with distilled water, denatured with $1 \%$ Tris-borate-EDTA (TBE) buffer for 40 min at $4{ }^{\circ} \mathrm{C}$. The slides were then subjected to electrophoresis for $20 \mathrm{~min}$ at $20 \mathrm{~V}$, followed by PBS washing and propidium iodide (PI, $2 \mu \mathrm{g} / \mathrm{mL}$ ) staining for $15 \mathrm{~min}$. Images were taken under a fluorescence microscope and analyzed by CASP software to determine the tail moment of the comet cells. More than 60 cells per group were included in the analyses.

\section{Cell cycle analysis by flow cytometry}

HepG2 cells were divided into four groups: control group (no chemical treatment or radiation), IR alone group ( $4 \mathrm{~Gy}{ }^{60} \mathrm{Co \gamma}$ ), NU7441 alone group (5 $\mu \mathrm{M}$ NU7441) and NU7441 + IR group (one hour before radiation exposure, $5 \mu \mathrm{M}$ NU7441 was added into the culture media). HepG2 cells at their log phase were treated with NU7441 for $12 \mathrm{~h}$ as described above. Cells were collected by trypsin digestion and centrifuged for three min at $2000 \mathrm{rpm}$ at $4{ }^{\circ} \mathrm{C}$. The cell pellets were washed three times with PBS, fixed with $70 \%$ ethanol at $-20^{\circ} \mathrm{C}$ for more than $12 \mathrm{~h}$, digested with RNase $(50 \mu \mathrm{g} / \mathrm{mL})$ for $30 \mathrm{~min}$ at $37{ }^{\circ} \mathrm{C}$, and stained with PI staining before flow cytometry.

\section{Data Analysis}

SPSS Statistical software 17.0 was used to analyze the experimental data. The results were expressed as mean \pm standard deviation. Two independent samples were analyzed by the $t$-test and several independent samples were analyzed by one-way ANOVA. $P<0.05$ indicates statistically significant difference.

\section{Results}

NU7441 inhibited cell growth

We first evaluated the effect of NU7441 on the growth of liver cancer HepG2 cells treated with different doses of NU7441, from 0.5 to $10 \mu \mathrm{M}$ (Fig. 1). CCK-8 kit was used to measure the cell numbers. The results in Figure 1 demonstrate the inhibitory effect of NU7441 on cell growth, indicating the potential application of this medicine to kill the cancer cells. Moreover, this inhibition was dose- and time-dependent, with a maximal inhibitory effect for $72 \mathrm{~h}$ at a dosage of $10 \mu \mathrm{M}$ NU7441.

NU7441 reduces $p D N A-P K c s$ (S2056) protein expression in liver cancer cells

NU7441 is a small molecule which specifically inhibits DNA-PK, a DNA dependent protein kinase. This DNA-PK forms a complex with Ku70 and Ku80 to participate in the DNA damage repair. In the prsesnt study, the protein expression of DNA-PKcs was considerably upregulated in the liver cancer HepG2 cells compared to the barely detectable level of 
Fig. 1. Inhibition of HepG2 liver cancer cell proliferation by NU7441. HepG2 cells were cultured with different doses of NU7441, and cell numbers were counted by CCK-8 kit, which is detailed in Materials and Methods. This inhibition was doseand time-dependent, and the maximal effect was achieved at $10 \mu \mathrm{M}$ at $72 \mathrm{~h}$.

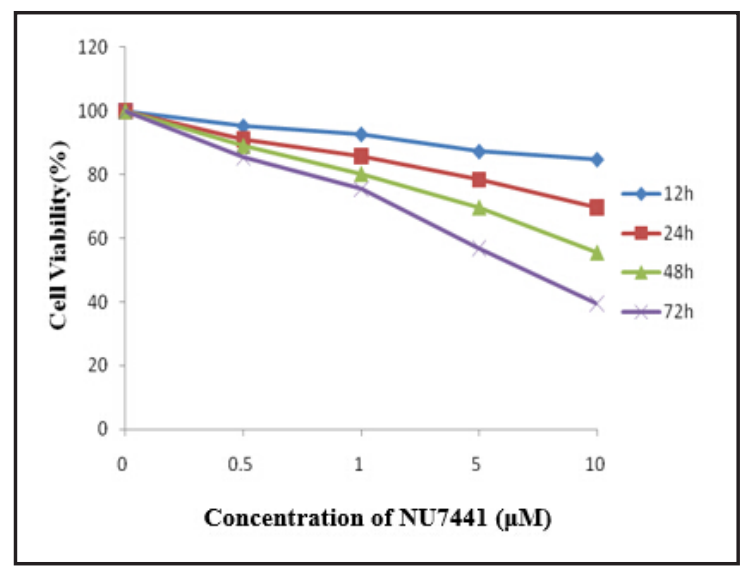

Fig. 2. Reduced pDNA-PKcs (S2056) expression by NU7441 and ${ }^{60} \mathrm{Co} \gamma$ IR double treatment. DNA-PKcs protein is abundantly expressed in the human liver cancer cells HepG2. This expression was further increased by ${ }^{60} \mathrm{Co} \gamma$ treatment (panel A). IR ( $\left.{ }^{60} \mathrm{Co} \gamma\right)$ and NU7441 double treatment synergized, reducing specifically pDNA-PKcs (S2056) levels, whereas those of the total DNA-PKcs protein and the other complex members Ku70 and Ku80 remained unchanged (Panel B). Meanwhile, compared to another DNA-PKcs inhibitor, NU7026, NU7441 had a greater reduction on pDNA-PKcs (S2056) expression (Panel C).

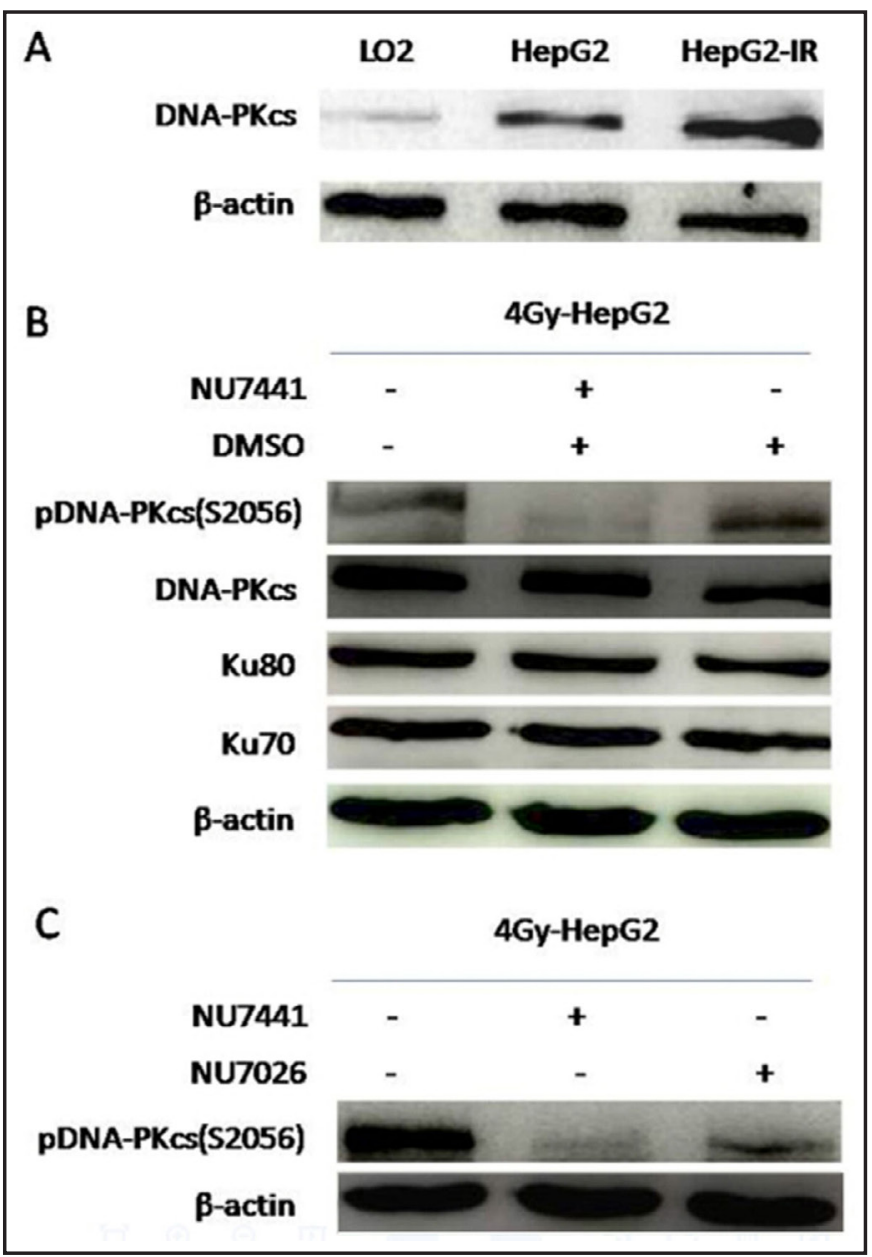

this protein in the normal liver cells LO2 (Fig. 2). Moreover, this upregulation was further enhanced by the treatment with ${ }^{60} \mathrm{Co} \gamma$ ionizing radiation; one hour of 4 Gy ${ }^{60} \mathrm{Co} \gamma$ radiation exposure increased DNA-PKcs protein level (Fig. 2, panel A). The elevated expression of DNA-PKcs implicates an important role of this protein in the development of liver cancer cells and their response to adverse stimulation. ${ }^{60} \mathrm{Co} \gamma$ radiation leads to DNA damage which can be fixed by the NHEJ system, where DNA-PKcs exerts a crucial function.

It is noteworthy that the inhibitor NU7441 did not change the total protein levels of Ku70, Ku80, and DNA-PKcs: the major components in the DNA repair machinery (Fig. 2, 


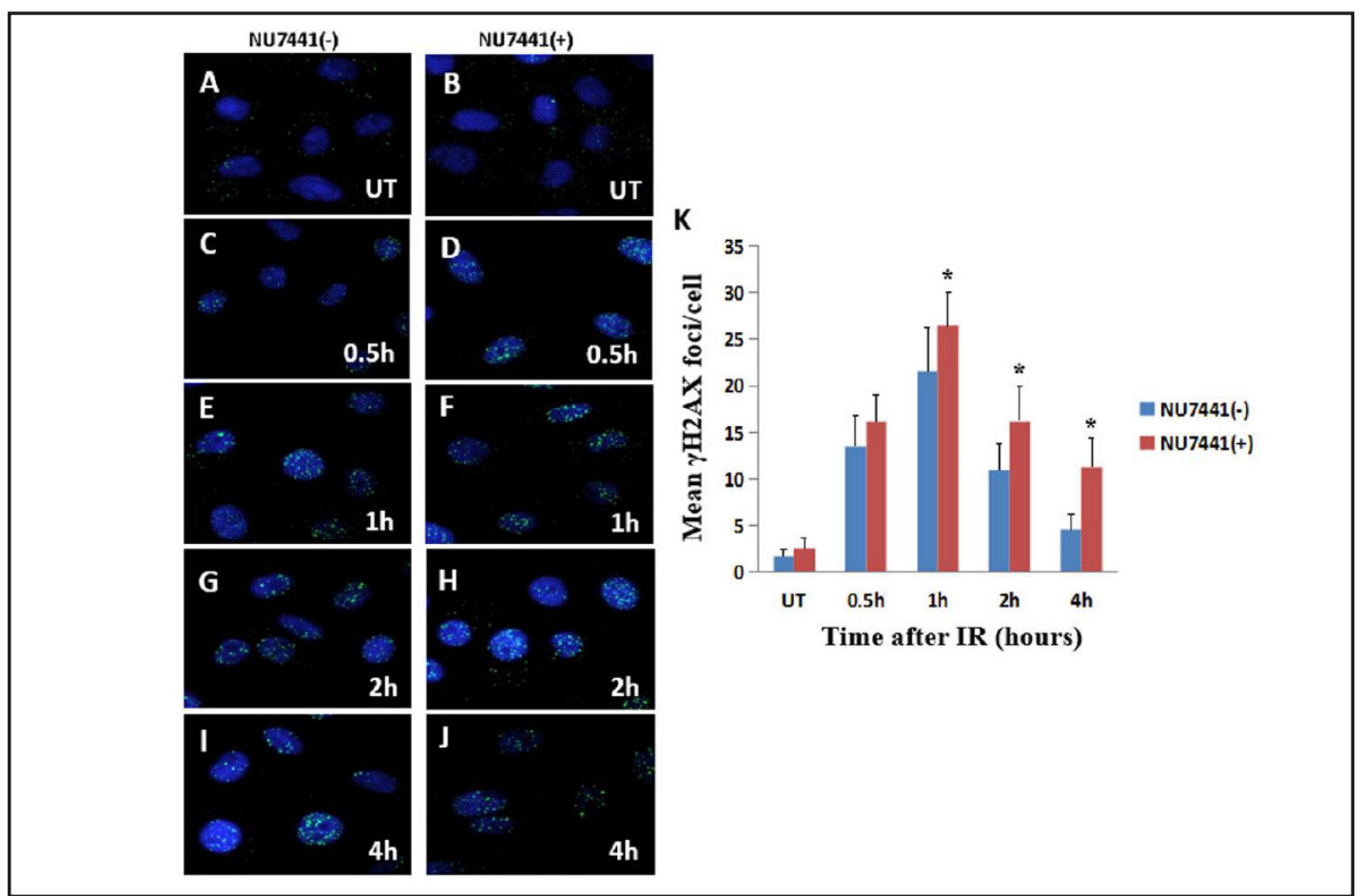

Fig. 3. NU7441 and IR double treatment $\gamma$ increased foci number in $\gamma \mathrm{H} 2 \mathrm{AX}$ immunostaining. H2AX, a sensitive marker for DNA double-strand breaks, was induced by NU7441 and IR double treatment. UT: untreated control. The foci of $\gamma \mathrm{H} 2 \mathrm{AX}$ staining reached maximal after one hour of NU7441 and IR treatment (Panel E and F), compared to the untreated control (UT, panel A and B), 0.5 hour of treatment (panel C and D). Then, it decreased at 2 and $4 \mathrm{~h}$ of treatment (panel G-J). The dynamic change of the foci number is depicted in panel K.

panel B). However, the amount of phosphorylated DNA-PKcs (S2056) was decreased sharply by the NU7441 treatment, indicating the specific role of this inhibitor.

We next consolidated this finding by comparing NU7441 with NU7026, another NDA-PKcs inhibitor. Both NU7441- and NU7026-treated cells reduced DNA-PKcs (S2056) expression. The expression level of phosphorylated DNA-PKcs (S2056) was substantially decreased, and the activity of DNA-PKcs was inhibited significantly by the NU7441 treatment compared to those in the NU7026 group.

\section{NU7441 $+{ }^{60} \mathrm{Co \gamma}$ IR double treatment affected DNA damage repair}

To probe the DNA damage and NU7442 action, we selected $\gamma \mathrm{H} 2 \mathrm{AX}$ : a sensitive marker for DNA damage and repair [18]. Immunofluorescence results showed that initially the number of $\gamma \mathrm{H} 2 \mathrm{AX}$ foci increased and decreased after one hour of NU7441 treatment (Fig. $3)$. The same result was obtained for the cells treated with NU7441, whereas the rate of decrease in the number of $\gamma \mathrm{H} 2 \mathrm{AX}$ foci was slower than that of the irradiated-alone group $(P$ $<0.05$, Fig. 3).

Next, we performed a comet assay, also called single-cell gel electrophoresis. This is a sensitive and rapid technology to determine DNA damage in individual cells. We compared the impacts on HepG2 cells treated with NU7441 alone, ${ }^{60} \mathrm{Co} \gamma$ alone (IR), and NU7441 + IR double. Our results indicated that DNA damage in HepG2 cells was induced after their exposure to $4 \mathrm{~Gy}{ }^{60} \mathrm{Co} \gamma$ radiation (Fig. 4). The values of the tail moments in the comet cells in the ${ }^{60} \mathrm{Co} \gamma$ radiated group were higher than those in the untreated group $(P<0.05)$. The repair rate of the group irradiated in the presence of NU7441 was slower than that in the single ${ }^{60}$ Coy group $(P<0.05$, Fig. 4$)$.

Finally, we implemented flow cytometry to quantify the DNA content using PI staining in HepG2 cells. Compared to the untreated control group, the proportion of cells at G2/M

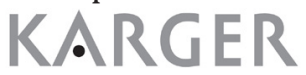



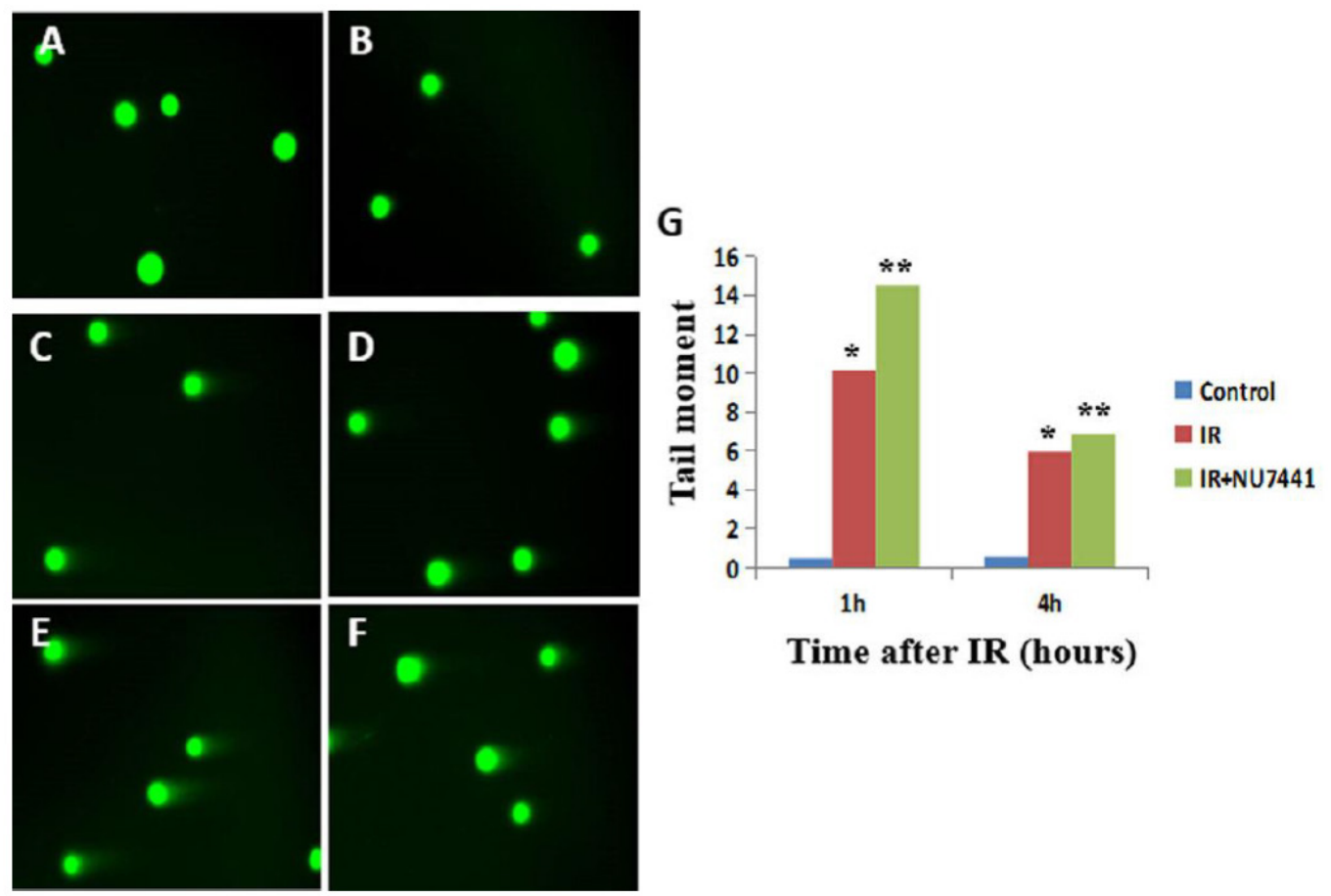

Time after IR (hours)

Fig. 4. Comet tail increased in single cell gel electrophoresis by NU7441 and IR double treatment. After 1 and $4 \mathrm{~h}$ of treatment with IR or IR+NU7441, HepG2 cells were subjected to the comet assay. Double IR and NU7441 treatments significantly increased the comet tail moment (panel E, F, and G), compared to the control (A and B) and the single IR group (C and D).

Fig. 5. Induction of cell cycle arrest at G2/M by IR and NU7441+IR double treatment in HepG2 cells. Flow cytometry was performed to quantify DNA by PI staining. Increased G2/Mphased cells were observed in the NU7441+IR double group (panel D) and single IR group (panel B). In contrast, considerably fewer G2/M-phased cells were detected in the control and NU7441 single treatment groups.

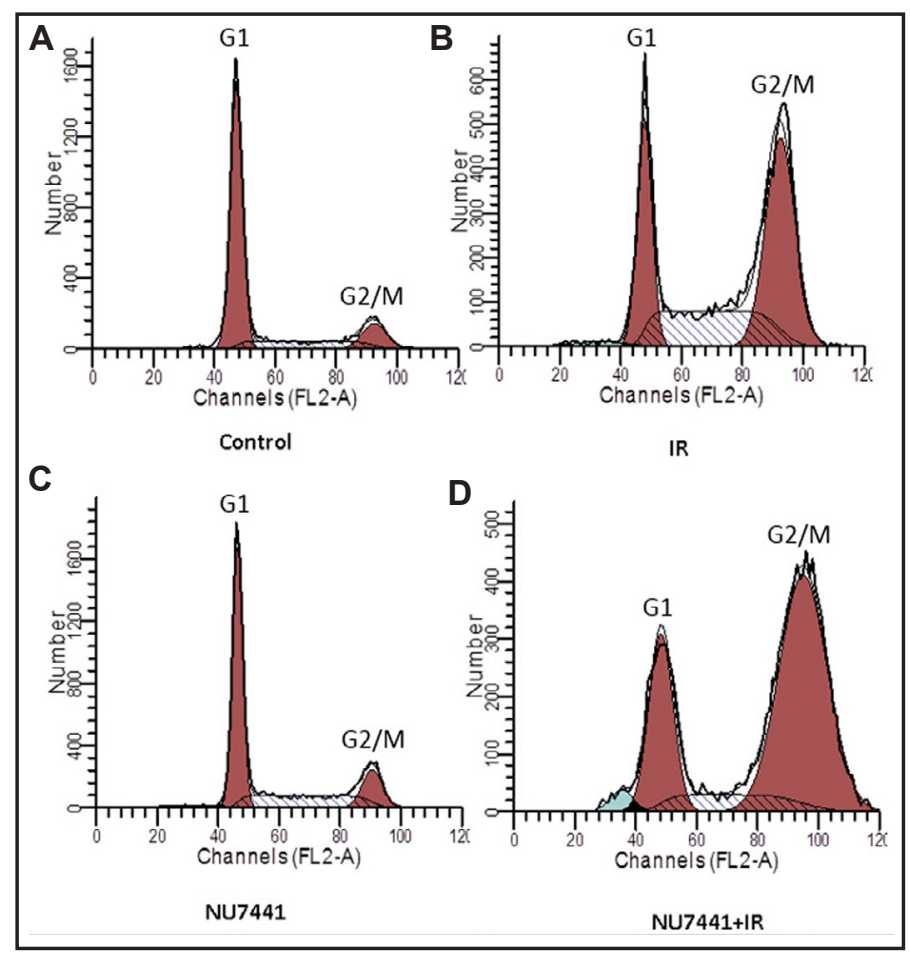

phase was dramatically increased in the IR group $(P<0.05$, Fig. 5$)$ whereas no statistically significant differences were established from the NU7441 group $(P>0.05)$. The percentage of cells at G2/M phase was increased in the treatment with NU7441 combined with IR when 
compared to that in the IR group $(P<0.05$, Fig. 5). The G2/M is an important cell-cycle checkpoint, and arrest at this stage indicates cell death [19].

\section{Discussion}

The results of this study revealed that NU7441 exerts an inhibitory effect on the proliferation of HepG 2 cells, and this activity is time- and dose-dependent. The suppressive action of NU7441 on DNA-PKcs activity is higher than that of NU7026 under the same conditions. NU7441 can enhance the radiosensitization of HepG2 cells by inhibiting the DNAPKcs activity of the DNA repair pathway, increasing the G2/M-phase arrest of the cell cycle and by inducing apoptosis. Therefore, the inhibitor NU7441 can be used as a radiosensitive drug for radiation therapy.

Radiation therapy becomes one of the major ancillary methods of liver cancer therapy $[20,21]$. The administration of ionizing irradiation results in double-strand breaks in the genomic DNA of the target cells. Liver cancer cells can repair their damaged DNA by nonhomologous end-joining [22], especially in the radiation-induced damage. This self-healing capacity of the liver cancer cells affects greatly the curative outcome of radiation therapy. Blocking this damage/repair pathway, especially by molecular targeting of the enzymes involved in this pathway can increase considerably radiation therapy effectiveness. Inhibiting DNA damage/repair mechanisms is a potent strategy for the improvement of the effect of radiotherapy on tumors [23].

Self-phosphorylation of DNA-PKcs occurs at the S2056 site [24], which provides a reliable marker for assessing the effect of tested drugs on the enzymatic activity of DNAPKcs. In this study, we found that NU7441 did not change the protein expression level of DNA-PKcs, Ku70, and Ku80, but specifically decreased the DNA-PKcs (S2056) protein level. Combined with radiation treatment, NU7441 induced cell-cycle arrest, apoptosis, and enhanced the sensitivity of the cancer cells [25].

Another inhibitor for DNA-PK, NU7026, was tested in the N87 gastric cancer cell line. NU7441 was demonstrated to have a higher specificity than NU7026 [26], which was supported by the findings of this study, indicating that, in HepG2 cells after 4 Gy ${ }^{60} \mathrm{Co \gamma}$ exposure, NU7441 exerts a more powerful inhibitory effect on DNA-PKcs activity than NU70264 Gy. $\gamma \mathrm{H} 2 \mathrm{AX}$ is a marker for DNA double-strand breaks. In H460, a human large cell lung cancer cell line, and A546, a human non-small lung carcinoma cell line, exposed to radiation [27], NU7441 increased the time of $\gamma \mathrm{H} 2 \mathrm{AX}$ foci existing [29]. Similar results were obtained in prostate cancer cells; NU7441 combined with radiation therapy prolonged the duration of $\gamma \mathrm{H} 2 \mathrm{AX}$ foci, slowed DNA damage repair, and induced G2/M cell-cycle arrest. Subsequently, apoptosis was increased [28, 29]. This study has obtained similar findings; the NU7441 treatment increased the number of $\gamma \mathrm{H} 2 \mathrm{AX}$ foci in the HepG2 cells under exposure of $4 \mathrm{~Gy}{ }^{60} \mathrm{Co \gamma}$. Our further investigations demonstrated that NU7441 inhibited DNA-PKcs activity and DNA damage repair. Similarly, the results of the neutral single-cell agarose electrophoresis assay showed that the DNA damage repair rate was reduced by NU7441. Both examinations led to the same conclusion: that NU7441 can enhance radiosensitization through inhibiting DNA damage repair. NHEJ can occur at any stage of the cell cycle. Our flow cytometry results indicated that NU7441 in combination with radiation exposure induced cell-cycle arrest at the G2/M stage and apoptosis.

Collectively, NU7441 can act as an inhibitor of DNA-PK, blocking DNA damage repair and cell cycle progression in liver cancer cells, which subsequently leads to their apoptosis. Therefore, as a radiation therapy enhancer, NU7441 provides a potential therapeutic option.

\section{Disclosure Statement}

All the authors declare that they have no conflict of interest.

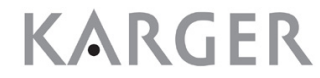




\section{Cellular Physiology Cell Physiol Biochem 2016;38:1897-1905 \begin{tabular}{l|l} 
DOI: 10.1159/000445551 & $\begin{array}{l}\text { O 2016 The Author(s). Published by S. Karger AG, Basel } \\
\text { www.karger.com/cpb }\end{array}$
\end{tabular} \\ Yang et al.: NU7441 Enhances Radiosensitivity}

\section{References}

1 Bosetti C, Turati F, La Vecchia C: Hepatocellular carcinoma epidemiology. Best Prac Res Clin Gastroenterol 2014;28:753-770.

2 Kim TH, Park JW, Kim YJ, Kim BH, Woo SM, Moon SH, Kim SS, Koh YH, Lee WJ, Park SJ, Kim JY, Kim DY, Kim CM: Phase i dose-escalation study of proton beam therapy for inoperable hepatocellular carcinoma. Cancer Res Treat 2015;47:34-45.

3 El-Serag HB: Epidemiology of viral hepatitis and hepatocellular carcinoma. Gastroenterology 2012;142:1264-1273 e1261.

4 Sherman M: Surveillance for hepatocellular carcinoma. Best Prac Res Clin Gastroenterol 2014;28:783-793.

5 Yu JI, Park HC: Considerations for radiation therapy in hepatocellular carcinoma: The radiation oncologists' perspective. Dig Dis 2014;32:755-763.

6 Chen X, Liu HP, Li M, Qiao L: Advances in non-surgical management of primary liver cancer. World J Gastroenterol 2014;20:16630-16638.

7 Belov OV, Krasavin EA, Lyashko MS, Batmunkh M, Sweilam NH: A quantitative model of the major pathways for radiation-induced DNA double-strand break repair. J Theoret Biol 2015;366:115-130.

8 Mladenov E, Magin S, Soni A, Iliakis G: DNA double-strand break repair as determinant of cellular radiosensitivity to killing and target in radiation therapy. Front Oncol 2013;3:113.

9 Takahashi A, Kubo M, Ma H, Nakagawa A, Yoshida Y, Isono M, Kanai T, Ohno T, Furusawa Y, Funayama T, Kobayashi Y, Nakano T: Nonhomologous end-joining repair plays a more important role than homologous recombination repair in defining radiosensitivity after exposure to high-let radiation. Radiat Res 2014;182:338-344.

10 Lee SH, Kim CH: DNA-dependent protein kinase complex: A multifunctional protein in DNA repair and damage checkpoint. Mol Cells 2002;13:159-166.

11 Qian Y, Ma J, Guo X, Sun J, Yu Y, Cao B, Zhang L, Ding X, Huang J, Shao JF: Curcumin enhances the radiosensitivity of u87 cells by inducing dusp-2 up-regulation. Cell Physiol Biochem 2015;35:1381-1393.

12 Zhang SX, Qiu QH, Chen WB, Liang CH, Huang B: Celecoxib enhances radiosensitivity via induction of g(2)-m phase arrest and apoptosis in nasopharyngeal carcinoma. Cell Physiol Biochem 2014;33:14841497.

13 Wang BF, Wang XJ, Kang HF, Bai MH, Guan HT, Wang ZW, Zan Y, Song LQ, Min WL, Lin S, Cheng YA: Saikosaponin-d enhances radiosensitivity of hepatoma cells under hypoxic conditions by inhibiting hypoxia-inducible factor-1alpha. Cell Physiol Biochem 2014;33:37-51.

14 Hu S, Fu S, Xu X, Chen L, Xu J, Li B, Qu Y, Yu H, Lu S, Li W: The mechanism of radiosensitization by ym155, a novel small molecule inhibitor of survivin expression, is associated with DNA damage repair. Cell Physiol Biochem 2015;37:1219-1230.

15 Ciszewski WM, Tavecchio M, Dastych J, Curtin NJ: DNA-pk inhibition by nu7441 sensitizes breast cancer cells to ionizing radiation and doxorubicin. Breast Cancer Res Treat 2014;143:47-55.

16 Tichy A, Durisova K, Salovska B, Pejchal J, Zarybnicka L, Vavrova J, Dye NA, Sinkorova Z: Radio-sensitization of human leukaemic molt-4 cells by DNA-dependent protein kinase inhibitor, nu7441. Rad Envir Biophys 2014;53:83-92.

17 Menon JU, Tumati V, Hsieh JT, Nguyen KT, Saha D: Polymeric nanoparticles for targeted radiosensitization of prostate cancer cells. J Biomed Mat Res A 2015;103:1632-1639.

18 Mah LJ, El-Osta A, Karagiannis TC: Gammah2ax: A sensitive molecular marker of DNA damage and repair. Leukemia 2010;24:679-686.

19 Ouyang G, Yao L, Ruan K, Song G, Mao Y, Bao S: Genistein induces g2/m cell cycle arrest and apoptosis of human ovarian cancer cells via activation of DNA damage checkpoint pathways. Cell Biol Int 2009;33:12371244.

20 Aitken KL, Hawkins MA: The role of radiotherapy and chemoradiation in the management of primary liver tumours. Clin Oncol 2014;26:569-580.

21 Kalogeridi MA, Zygogianni A, Kyrgias G, Kouvaris J, Chatziioannou S, Kelekis N, Kouloulias V: Role of radiotherapy in the management of hepatocellular carcinoma: A systematic review. World J Hepatol 2015;7:101-112.

22 Mahaney BL, Meek K, Lees-Miller SP: Repair of ionizing radiation-induced DNA double-strand breaks by non-homologous end-joining. Biochem J 2009;417:639-650. 


\section{Cellular Physiology Cell Physiol Biochem 2016;38:1897-1905 \begin{tabular}{l|l|l} 
DOI: 10.1159/000445551 & $\begin{array}{l}\text { O 2016 The Author(s). Published by S. Karger AG, Basel } \\
\text { wwww.karger.com/cpb }\end{array}$ \\
\hline Published online: May 09, 2016 Biochemistry
\end{tabular} \\ Yang et al.: NU7441 Enhances Radiosensitivity}

23 Mould E, Berry P, Jamieson D, Hill C, Cano C, Tan N, Elliott S, Durkacz B, Newell D, Willmore E: Identification of dual DNA-pk mdr1 inhibitors for the potentiation of cytotoxic drug activity. Biochem Pharmacol 2014;88:58-65.

24 Chen BP, Chan DW, Kobayashi J, Burma S, Asaithamby A, Morotomi-Yano K, Botvinick E, Qin J, Chen DJ: Cell cycle dependence of DNA-dependent protein kinase phosphorylation in response to DNA double strand breaks. J Biol Chem 2005;280:14709-14715.

25 Niazi MT, Mok G, Heravi M, Lee L, Vuong T, Aloyz R, Panasci L, Muanza T: Effects of dna-dependent protein kinase inhibition by nu7026 on dna repair and cell survival in irradiated gastric cancer cell line n87. Current Oncol 2014;21:91-96.

26 Leahy JJ, Golding BT, Griffin RJ, Hardcastle IR, Richardson C, Rigoreau L, Smith GC: Identification of a highly potent and selective DNA-dependent protein kinase (DNA-pk) inhibitor (nu7441) by screening of chromenone libraries. Bioorgan Med Chem Lett 2004;14:6083-6087.

27 Azad A, Bukczynska P, Jackson S, Haupt Y, Cullinane C, McArthur GA, Solomon B: Co-targeting deoxyribonucleic acid-dependent protein kinase and poly(adenosine diphosphate-ribose) polymerase-1 promotes accelerated senescence of irradiated cancer cells. Int J Rad Oncol Biol Physics 2014;88:385-394.

28 Shaheen FS, Znojek P, Fisher A, Webster M, Plummer R, Gaughan L, Smith GC, Leung HY, Curtin NJ, Robson CN: Targeting the DNA double strand break repair machinery in prostate cancer. PloS One 2011;6:e20311.

29 Yu L, Tumati V, Tseng SF, Hsu FM, Kim DN, Hong D, Hsieh JT, Jacobs C, Kapur P, Saha D: Dab2ip regulates autophagy in prostate cancer in response to combined treatment of radiation and a DNA-pkcs inhibitor. Neoplasia 2012;14:1203-1212. 